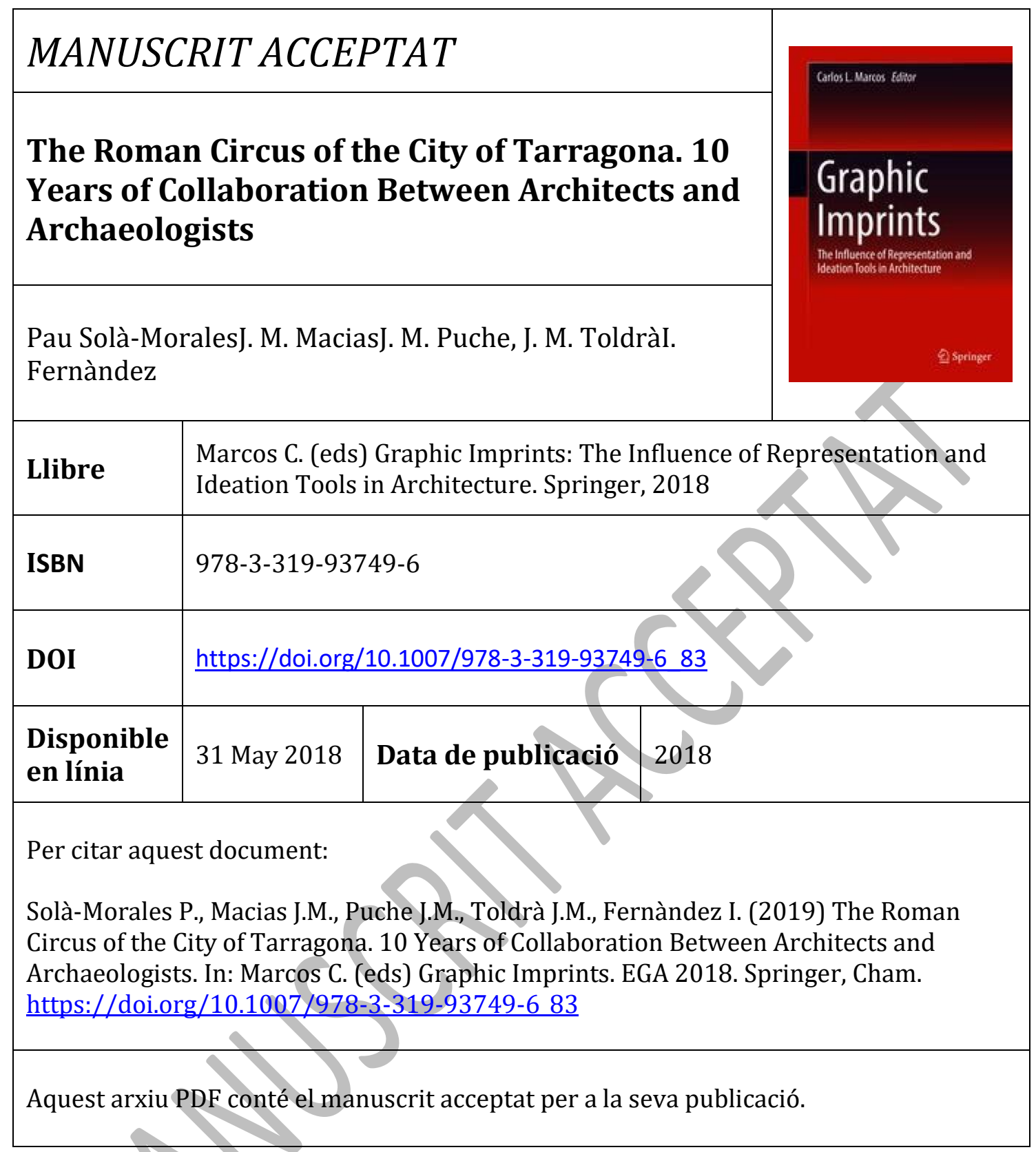




\title{
The Roman circus of the city of Tarragona. 10 years of collaboration between architects and archaeologists
}

\author{
Solà-Morales, P. (1), Macias, J.M. (2), Puche, J.M. (2), Toldrà, J.M. (1), Fernàndez, I. (1) \\ 1: School of Architecture -URV 2: Catalan Institute of Classical Archaeology
}

\section{Abstract: The Roman circus of the city of Tarragona. 10 years of collaboration between architects and archaeologists}

We are not the first to deal with the Roman circus of Tarragona, perhaps one of the most drawn Roman buildings of the Iberian Peninsula, although the insistence in its documentation has not produced a complete and convincing planimetry. The complicated articulation of the circus with the historical centre of the city makes it difficult to elaborate a reliable synthesis of its architectural configuration. But, taking advantage of the potential in the collaboration between the Technical School of Architecture (ETSA) of the Rovira i Virgili University (URV) and the Catalan Institute of Classical Archaeology (ICAC), it is also an opportunity to combine the different skills of architects and archaeologists for the interpretation of historical architecture.

Aware of the deficiencies in the graphic documentation of the Roman circus of Tarragona, it was decided to choose this monument as an area of methodological test, where the students of the subjects mentioned above have developed their practical works.

The final result is a heterogeneous set of graphic representations of the same monument, product of the different visions of its authors and of the evolution of the techniques used in their elaboration. In the present communication we show a synthesis of the works carried out, thanks to which a more intense approach to the reality of the circus is achieved, understanding that the richness of the architectural ensemble comes from both the Roman remains and their overlap with the medieval and contemporary urban form of the historic centre of Tarragona.

Keywords: Tarraco; Drawing; Archaeology; roman circus; MDCS

\section{Introduction}

When a whole roman circus, with an extension of four hectares, is an indivisible part of a contemporary city with an historical and historiographical tradition, such as that of Tarragona, there is -understandably and fortunately- a cartographic and graphic legacy of great magnitude. This reflects the evolution of resources and precepts of the graphic documentation, but also the technological limitations inherent to each historical period. On the one hand, the cartographic documentation of the circus is abundant because the city was a military center until the middle of the $19^{\text {th }}$ century, and the circus' remains were part of its defensive system. These documents already show the incidence of the monument in the configuration of the topography of the city's historical precinct. And, on the other hand, starting with the professionalization of archaeology in the 1980's, the planimetries obtained in subsoil excavations have proliferated, even though numerous and old urban reforms have caused irremediably patrimonial destructions, in some cases. (See historical cartography compilation in Dupré et alii 1988 and technical documentation in Macias et alii 2007).

For all these reasons, after almost forty years of documentation there is abundant and varied technical information, produced by different hands and different technological resources. But the imprecision of the municipal topographical base -used as a reference-, obtained in yesteryear from aerial orthophotos, 


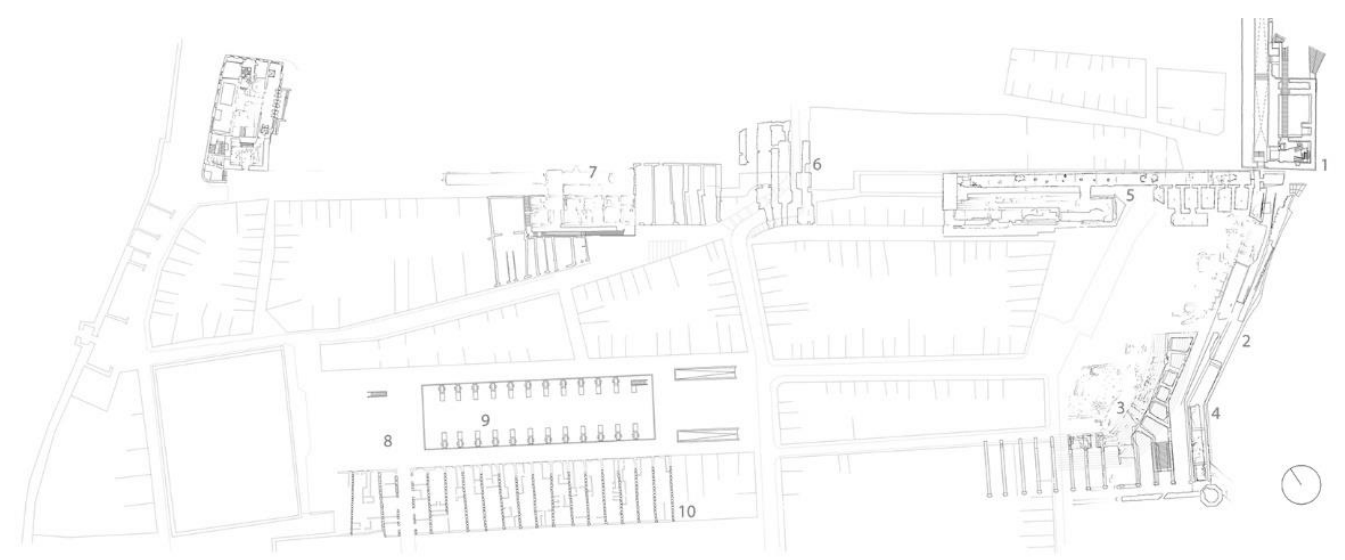

Figure 1: Main structures of the monumental complex of the Roman circus of Tarragona:

1. Pretori Tower, 2. Porta Triumphalis, 3. South half of the circus stands 4. Roman walls, 5. Support structures of the northeast stands, 6. Support vaults of the Pulvinar,

7. Vaults of the northwestern stand, 8. Font's square (the circus arena), 9. Underground parking, 10. Buildings resting on supporting walls of the south stands 11. Old Audiència Tower.

together with the variability of the "traditional" topographical basepoints -often hidden or transformed by the modifications of the paved streets-, make it impossible to unify, precisely and in three-dimensions, the information collected in a building of this magnitude and complexity (Figure $1)$.

In this context it is worth mentioning the collaboration between the School of Architecture of the Universitat Rovira i Virgili (ETSA-URV) and the Catalan Institute of Classical Archaeology (ICAC) for the documentation of the historical heritage of the city.

It is a research included in the activities of Research Group on Architectural Heritage and Archaeology ARCHCRA (ICAC-ETSA/URV).It is not solely a technical update, based on the new MDCS or topographic bases positioned by GPS, but it has also been a dialectical scenario, not always coincident, between archaeological and architectural methods and reasoning (Solà-Morales et alii 2014).

\section{Characteristics and problems of the roman circus}

The current city of Tarragona -the ancient Tarracowas the port of entry of the Roman Empire in the Iberian Peninsula. It was an Iberian settlement from the 6th century B.C. and, due to its geostrategic characteristics, it acquired relevance in the conquest and the subsequent hierarchical urban structuring of Hispania. Tarraco reached the capital of the prouincia Hispania Citerior, during three centuries the largest in the Empire. Tarraco developed a great monumental project on top of the hill, where there was an extensive militarized zone, in the military context of the conquest. The availability of public land allowed, with the arrival of Pax Augusta, to raise a 19Ha monumental sector inside the walls, articulated around a square of worship to the emperor, and a square of administration and political representation. And, at its feet, the Roman circus, as a closing area with respect to the residential city.

Among the Imperial circus architectures, this intramural situation constitutes an exception since these precincts, because of their extension, were traditionally located in the surroundings of the city, where the land value was lower. Its urban position was the cause that, besides being a ludic building, it was an element of separation and road connection between the upper squares and the lower city. The circus had to articulate the bidirectional traffic of the Tarraconenses between both urban sectors. Therefore, its constructive solidity was based on a skeleton of caementa that has made the building a perennial and determinant element in the urban development of Tarragona.

Over the centuries a symbiotic relationship has been established between the building and various 
overlapping urban events, in a process that -at the same time- demolished and preserved its architectural vestiges. Most of the walls of stone ashlars were extracted and reused in the medieval or modern city. But each wall of lime mortar that was reused as a foundation was a preserved vestige for the documentation of the future. At an urban and historical level, three processes stand out. The first has been the stratigraphic superposition on the Roman remains, produced from the urban reforms of the medieval period. It was during this period that the major transformations took place, as a new road network was created that compartmentalized the circus arena and created a new circulation structure. Some streets were traced inside the arena, and others over the old stands defining the current urban appearance. While both these processes occurred on the outside of the architectural remains, a third one occurred in the very inside of the Roman building: the reuse of the lime-and-mortar-concrete vaults that supported the old stands. In this way, all the vaults were reused as old warehouses and, nowadays, as ludic centres or restaurants, within the process of tourist transformation of the historic centre.

All these factors, together with other specific events, are the challenges that hinder the comprehension and global documentation of the building. But at the same time, they constitute a diachronic story about the city's historical evolution and the technological destructive processes of our society .

\section{Interdiscipline and training}

Since its foundation in 2005, the School of Architecture of Rovira i Virgili University (ETSA-URV) has collaborated with the Catalan Institute of Classical Archaeology (ICAC) in the field of architectural heritage. The School's interest in expanding its research and academic horizons has required looking for interdisciplinary work spaces, on the one hand, and developing a research niche in which to develop and disseminate its own "personality", on the other. This will has led them to the territories of archaeology, and especially to all that concerns the subdiscipline of "archaeology of architecture" and "archaeology of construction". In this framework, architects contribute their technical, constructive and drawing knowledge, while archaeologists provide the historical context and its descriptive and stratigraphic rigor. The fruits of this coexistence should not be limited to the study of the past, but also to the diachronic analysis of our heritage reality -in many cases the result of processes of transformation, durability and readaptation. Thus, new graduated architects will take full consciousness of the diachrony of our historical architecture and will be knowledgeable of the complexity of its study for a correct conservation or restoration (Figure 2).

In this context, we are aware of the shortcomings in the

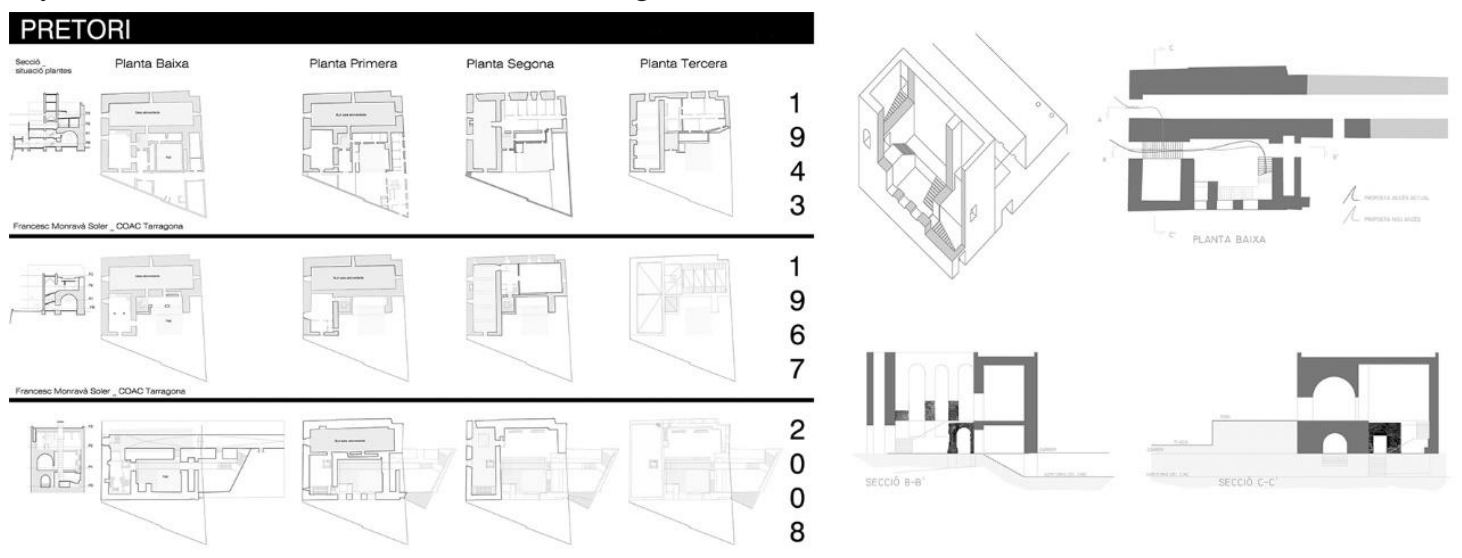

Figure 2: Plans of different phases of use of the Pretori Tower; hypothesis of vertical communication routes in Roman times.

resources that characterized the constructive and graphic documentation of the Roman circus of 
Tarragona. This historical site was precisely chosen as a case of study, learning and methodological experimentation. Both research and teaching processes evidence how the superposition of modern structures on previous remains hinders not only the understanding of the latter, but also prevents the elaboration of a coherent and lasting plan of intervention, restoration or musealization. In our case, the fragmentary knowledge of the architectural remains, both in plan or in three dimensions, is one of the reasons for the absence of a Master Plan for the Roman circus in Tarragona. Any intervention on a living, inhabited and dynamic city requires a thorough knowledge of its architectural and technological reality.

This activity has demonstrated the potential of new technological resources in architectural documentation, whose constant evolution requires a quick experimentation and updating of means. Thus, the new massive data capture systems (MDCS) allow the three-dimensional comprehension of the architectural reality and easily overcome the drawbacks derived from the urban complexity fragmentation and covering- of the monument in its current role as inhabited spaces (Puche et alii 2017). The use of laser scanner has allowed us to digitally visualize in three dimensions and understand the construction process of a four-hectare building, along with traditional photogrammetric techniques, provide a volume of documentation infinitely superior to the traditional archaeological drawing, while the new hardware and software increasingly allow to manage architectural space as an organized and structured digital reality -and on a graphic scale very close to reality! For all these reasons, we can create digital clones of the heritage reality. The models generated in this project can be seen on the online $3 \mathrm{D}$ visualization platform Sketchfab: https://skfb.ly/66Sys, https://skfb.ly/6oXAq, https://skfb.ly/66YMw.

Despite these technological resources, we insist, as an unavoidable phase of the learning process, to maintain the old graphic techniques of documentation of archaeological and architectural heritage. We refer to the different graphic representation systems available: traditional (plan - section - elevation, sketches, etc.), modern (computer-aided design, topography, photography, etc.), or "very modern" such as the ones mentioned before. But, in any case, our interest has not focused on the techniques, but on the practical salvaging of drafting as a medium for analysis and interpretation. In other words, the new architectural heritage professionals must be able to understand, discern, and interpret a building as it is being drawn and represented. This last process includes its graphic representation and the selection of illustrative "visual segments" of architectural globality (Figure 3).
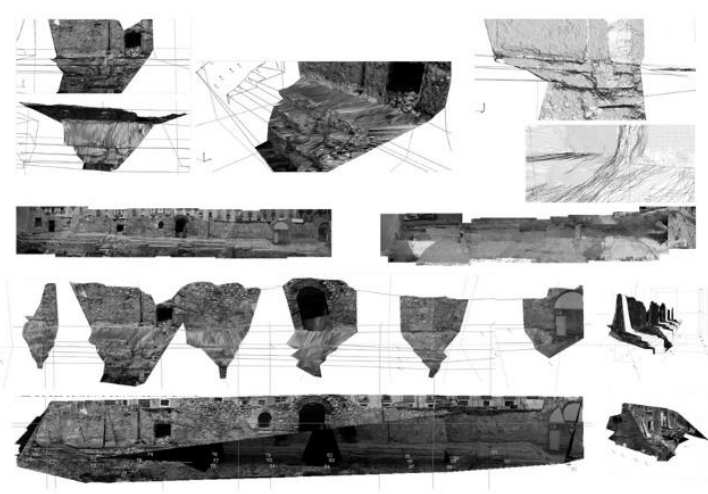
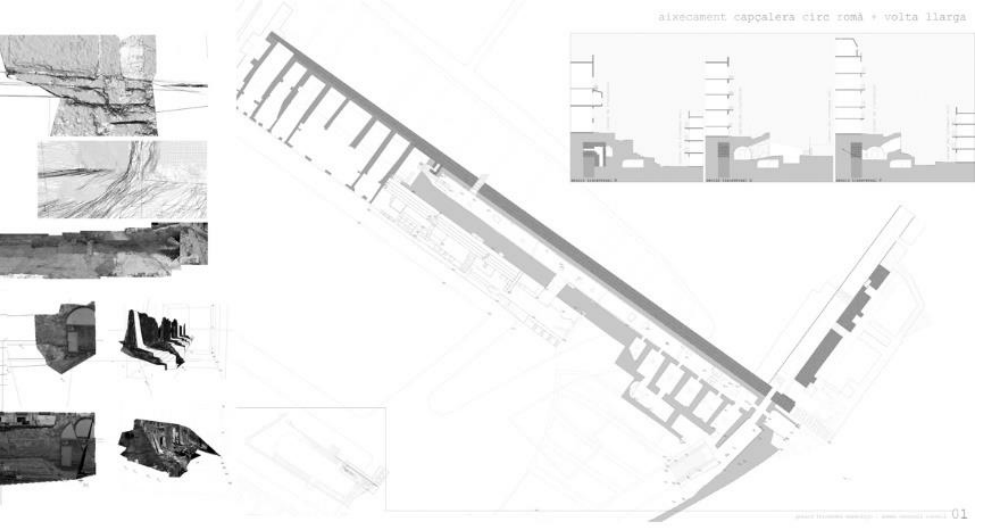

Figure 3: Tests of photogrammetric applications. Eastern sector of the northern tier of the circus in 3D. Survey with conventional topographical means of stand support structures.

intensely altered from the transformations that occurred from the 5th century on. MDCS methods,
In the process of conveying data -automatically retrieved- to freehand drawing (although it can be done 
with computer programs), the magic of the identification and representation of knowledge takes place: a magic or wisdom that, in our opinion, has been lost with the introduction of massive data capture systems, so common today. The activities of photography and laser scanning have generated, with their automatisms, a substantial loss of knowledge and reflexive and interpretative capacity. In other words, looking at the screen, we have moved away from the contemplation in situ in front of a wall.

Thus, we have constantly insisted on the completion, of non-hierarchical sketches with dimensions and information coming out of classic topographic surveys, digital photogrammetry and laser scans of different types. All this has been complemented by an epistemological reflection on each of these processes, their specific practicality, and the different ways of showing and interrelate, the results obtained.

One of the tools of ETSA and ICAC's collaboration has been teaching in the framework of a course, part of the Degree of Architecture taught at the ETSA. Initially it was named "Representation Techniques of Architectural Heritage", and later "Virtual Representation and Restoration". This course has three objectives: first, to incorporate in the education stages a technical and professional concern for

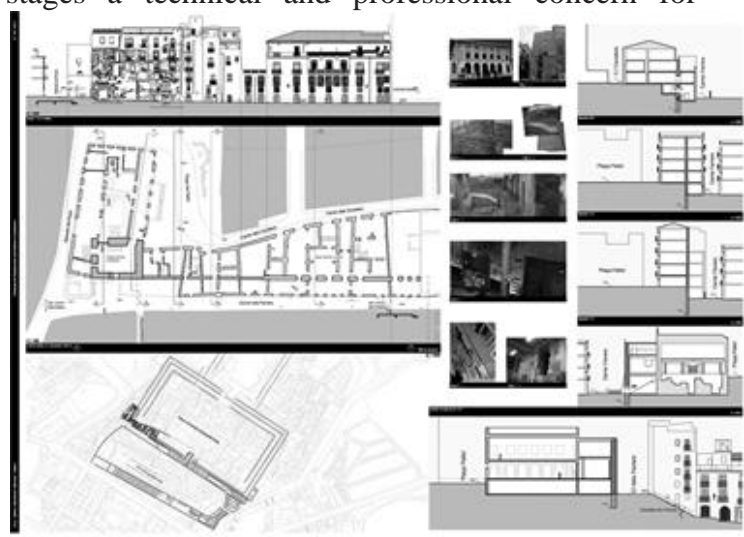

the interpretation of the archaeological and historical elements of heritage. Therefore, students are introduced to the understanding of historical architecture, always taking the document as a point of reference. As an elective subject of the last year, we have also been interested in tackling the most advanced aspects of research and procedure, and establishing a lab environment in the classroom, where teachers and students work together in workshop mode, developing ideas and testing new techniques and work methodologies.

\section{Conclusions}

The final result of these 10 years of joint work is a heterogeneous compendium of graphic representations of the same monument. It is the product of the different views of its authors and the evolution or interrelation of the techniques used in their elaboration. In other words, a sample of the rich variability of the "graphic representations of the city", that can be obtained from a significant patrimonial referent (Figures 4 to 9).

Given the circumstance that the documentation process does not discriminate between all the historicalarchitectural components, the obtained result allows us

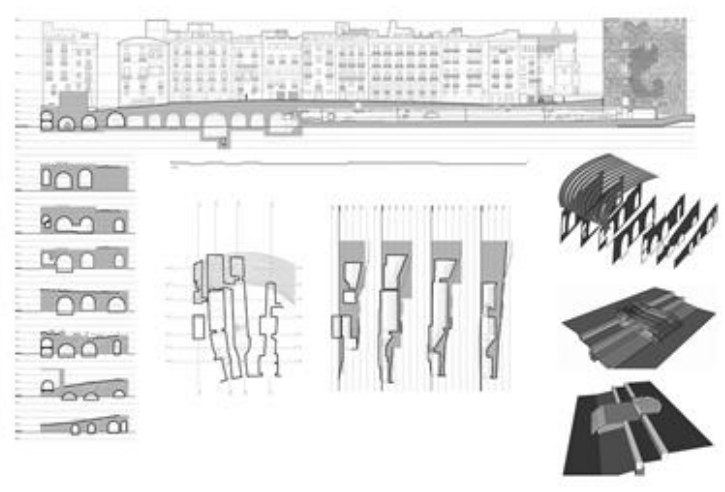

Figure 4: Survey and redrawing, from existing documentation, of the northem structures of the circus, from the Pretori Tower to Antigua Audiència Tower.

heritage; second, to equip the students with advanced heritage documentation techniques, which complement their already advanced expertise in architectural drawing; and finally, an introduction to 

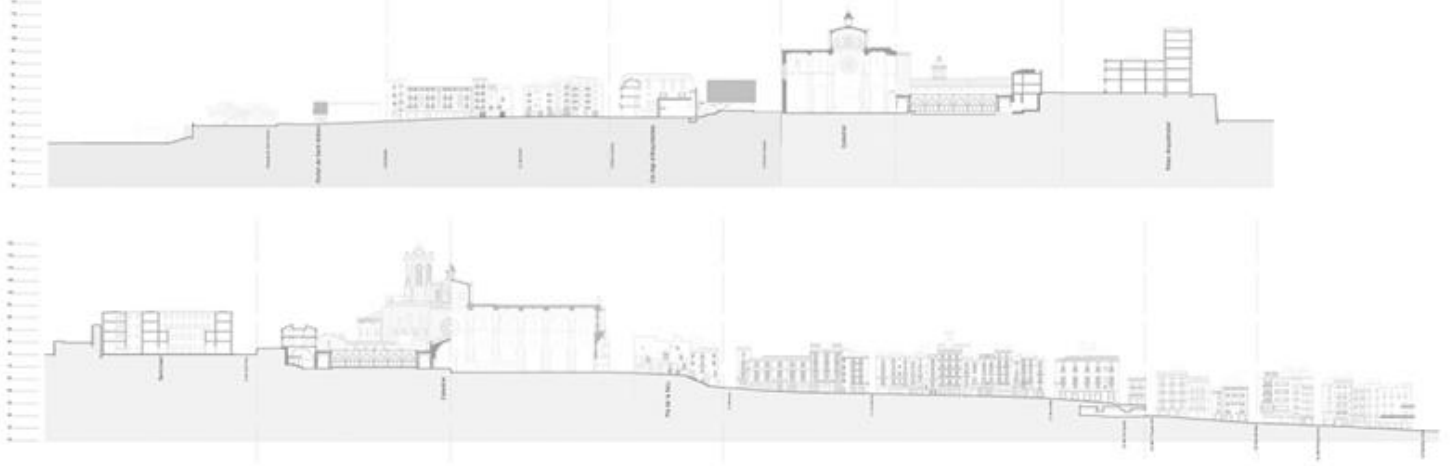

Figure 5: Sections of the historic centre of Tarragona, known as "Part Alta", which coincides with the Roman acropolis that housed the great imperial structures of the Concilium Prouinciae. Tarraconense. The upper section goes from east to west and the lower section from north to south.

to appreciate that the richness of the set does not come exclusively from the Roman remains but also from the superposition of structures from other periods. In other words, it is precisely the exceptionality of the overlay that gives an important value to the patrimonial complex of Tarragona. In the future, it will allow us to elaborate knowledge transfers with a transversal interest: the understanding of the Roman city, but also the diachronic understanding of the urban space where citizens live and express themselves civically. knowledge that requires an effort to be represented, and to individualize such superposition. It should reflect the periodization, the reuse of materials and structures, the stratigraphic relationships. In short, to understand the different layers that make up the current city (without forgetting any), preparing an interpretative work of urban evolution (Fernández et alii 2017, Solà-Morales et alii 2017).
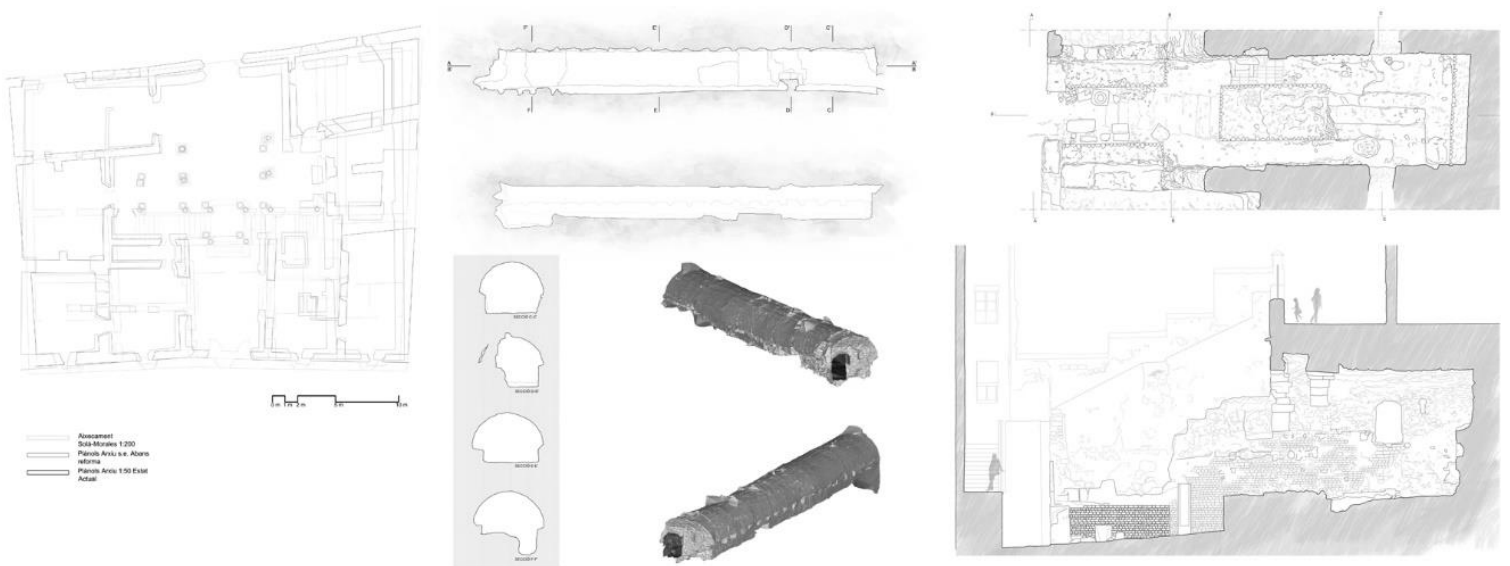

$\square=$
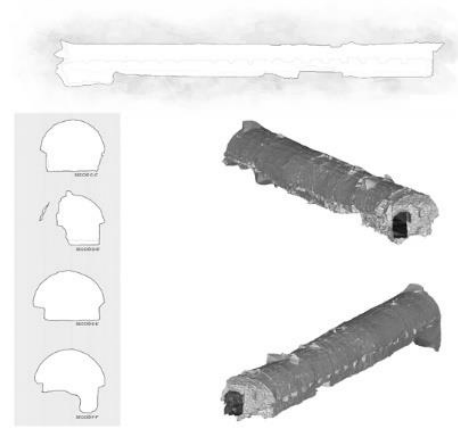

Figure 6: Comparisons between different surveys of structures built on the NWsector of the circus. Redrawing of the underground structures that supported the stands of same sector, from laser scanner surveys.

In addition, the knowledge of the underlying building explains the reasons of the urban design of the medieval city. In this way, we obtain an indirect 

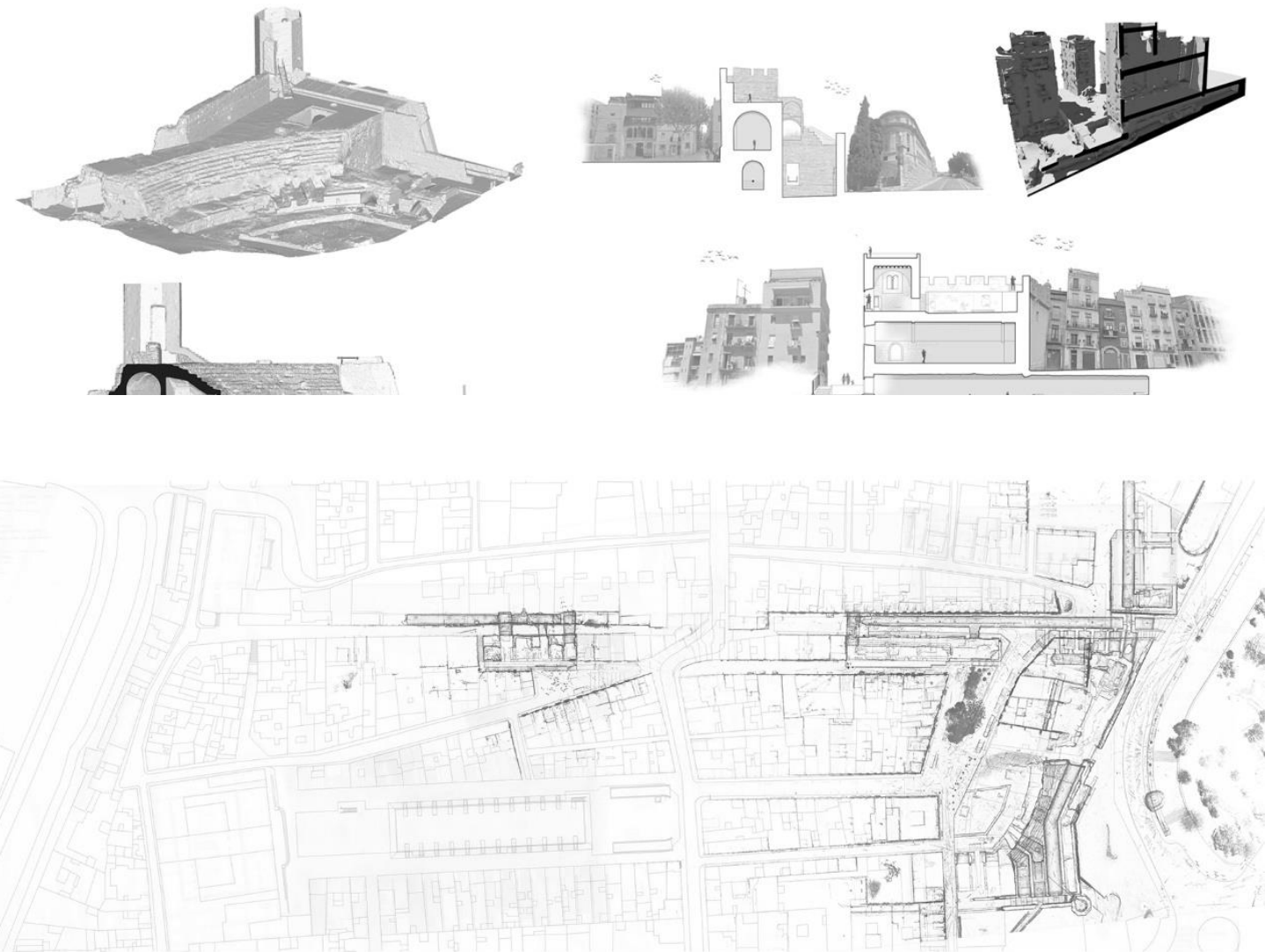

Figure 8: Superimposition of official planimetry of the City Council of Tarragona and laser scanner survey

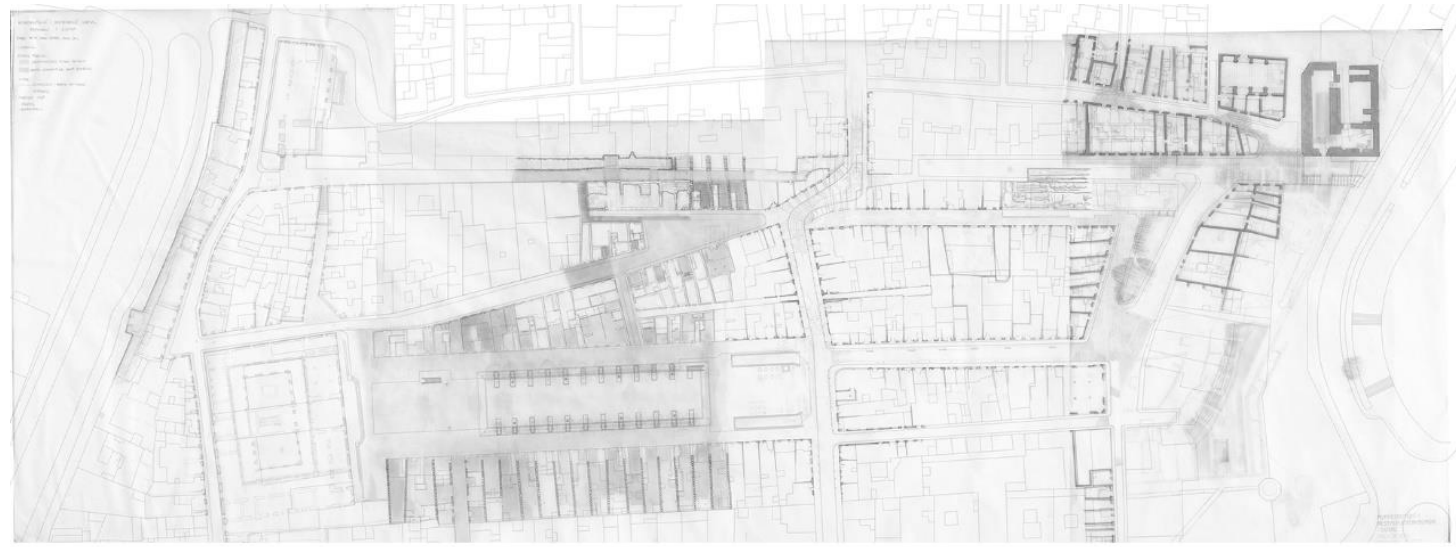

Figure 9: Manual redrawing of the public roads and the ground floors of circus, taking as a reference base the laser scans, the official planimetry and conventional surveys.

Finally, at the strictly archaeological level, the documentation and analysis carried out has allowed us to elaborate numerous typical sections of the circus' building, as well as sections of the contemporary urban fabrics. In this way, we have elaborated a joint plan of all the architectural vestiges, either in point-cloud or in a re-worked, vectorized file. In addition, all this information is georeferenced, with a 
series of considerations in relation to the slant of the building site, possible slopes of rainwater evacuation, etc.

Another significant aspect is the section of the conserved vestiges in the subsoil, in relation to the streets and blocks of overlapping houses. For the first time, we have sections of the thickness of the streets superimposed on the circus, and useful information for the layout of urban services: sewers, power lines, etc. The graphic analysis identifies doors and stairways of the stands, as well as the establishment of hypotheses of spectator capacity and itineraries of access or evacuation. In the future, obtaining threedimensional models will allow us to make an approximate calculation of the volume of mortar material used in the construction of the building, weight loads, stratification of the construction process, etc.

In short, archaeologists and architects are aware of their coinciding spaces, establishing future bases of collaboration, which do not exclusively affect the world of research but also the field of architectural restoration and musealization of heritage.

\section{Acknowledgments}

The research leading to these results has received funding from

MINECO-FEDER (Analyticalevolutionary parameters of the construction techniques of the northeast of Tarraconense in Late Antiquity:homogenization, criteria of representation and calibration, ref. HAR2015-64392-C4-2P) and the project ARREL (Recercaixa 2015, Obra Social "la Caixa" and ACUP).

\section{Bibliography}

Solà-Morales, P., Toldrà, J.M., Puche, J.M., Macias, J.M. (2014). Redrawing Tarraco in XII International Forum Le vie dei Mercanti. Best practice in heritage conservation management. Aversa-Capri

Puche, J.M., Solà-Morales, P., Toldrà, J.M., Macias, J.M., Fernández, I, (2017). Mobile Mapping and laser scanner to interrelate the city and its heritage: the Roman Circus of Tarragona in REHAB 2017 Proceedings of the 3rd International Conference on Preservation, Maintenance and Rehabilitation of Historical Buildings and Structures. Braga

Fernàndez, I, Macias, J.M., Solà-Morales, P., Toldrà, J.M., Puche, J.M.,( 2017). Metodología de análisis del circo romano de Tarragona y nuevos resultados. in Roldan et alii. Ed. Modelos constructivos y urbanísticos de la arquitectura de Hispania. Tarragona pp 117-135

Solà-Morales, P., Toldrà, J.M., Puche, J.M., Macias, J.M., Fernández, I. (2017). Architectural Graphic Expression not Drawn A Digital Approach. in E. Castaño and E. Echevarría Ed. Architectural Draughtsmanship. From analog to digital narratives.. Ed. Springer. Switzerland. Pp 295-307

Dupré, X., Massó, J., Palanques, M.Ll., Verduchi, P. (1989). El Circ Romà de Tarragona I. Les Voltes de Sant Ermenegild, Barcelona

Macias, J.M., Fiz, I., Piñol, Ll., Miró, M., Guitart, J. (2007). Planimetria Arqueològica de Tarraco. Atles d'Arqueologia Urbana de Catalunya, 2. Documenta 5. Tarragona. 
Ivan Fernàndez Pino. Architect specializing in architectural heritage. Collaborator of the Catalan Institute of Classical Archaeology (ICAC) and the School of Architecture of the Rovira i Virgili University. His research is centered in the graphical documentation and the application of BIM systems in the architectural heritage.

Josep M. Macias Solé. Senior researcher at the Catalan Institute of Classical Archaeology (ICAC). His research is centered on the urbanism of late-antiquity. He has directed several research projects, and was one of the coordinators of the 'Archaeological Planimetry of Tarraco' (2007), that has allowed the topographical and diacronocal localization of Roman structures in the capital city of Hispania Citerior.

Josep M. Puche Fontanilles. Member of the Graphical Documentation Unit of the Catalan Institute of Classical Archaeology (ICAC). His research is focused on the graphical language of archaeological representation, as well as in the application of optical massive data acquisition systems to survey historical buildings with heritage value.

Pau Solà-Morales. Tenured professor and dean of the School of Architecture of the Rovira I Virgili University. He teaches Architectural representation techniques, and architectural theory. His research revolves around the modes and techniques of the digital representation of architecture and the data structures related to them.

Josep M. Toldrà Domingo. Researcher at the School of Architecture of Rovira i Virgili University. He doubles his activity as a practicing architect with the teaching of design studio and drawing courses. His research focuses on the geometry of historical buildings. 